\title{
Productivity of orchard grass (Dactylis glomerata L.) alone and associated with perennial ryegrass (Lolium perenne $L$.) and white clover (Trifolium repens $L$.)
}

\author{
María de los Ángeles Maldonado Peralta ${ }^{1}$, Adelaido Rafael Rojas García ${ }^{1 *}$, Nicolás Torres \\ Salado ${ }^{1}$, Jerónimo Herrera Pérez¹, Santiago Joaquín Cancino², Joel Ventura Ríos ${ }^{3}$, Alfonso \\ Hernández Garay ${ }^{3}$, Filogonio Jesús Hernández Guzmán ${ }^{4}$
}

\footnotetext{
${ }^{1}$ Universidad Autónoma de Guerrero, Unidad Académica de Medicina Veterinaria y Zootecnia N², Cuajinicuilapa, Guerrero, México.

2 Universidad Autónoma de Tamaulipas, Facultad de Ingeniería y Ciencias, División de Estudios de Posgrado, C. U. Ciudad Victoria, Tamaulipas, México.

${ }^{3}$ Colegio de Postgraduados, Posgrado de Recursos Genéticos y Productividad-Ganadería, Montecillo, Texcoco, México.

${ }^{4}$ Universidad Politécnica de Francisco I. Madero, Tepatepec, Hidalgo, México.
}

\begin{abstract}
The objective of this research was to evaluate the productive capacity of orchard grass alone and associated with perennial ryegrass and white clover sown at different proportions. Treatments consisted of the following associations and monoculture: 100-00-00, 70-20-10, 50-00-50, 40-40-20, 40-20-40, 20-70-10, 20-40-40, and 00-50-50\% of orchard grass, perennial ryegrass, and white clover, respectively. The eight treatments were randomly distributed into 24 experimental plots of $9 \times 8 \mathrm{~m}$ according to a completely randomized block design with three replicates. On average, the associations that had the highest herbage yield in two years were 40-20-40, 20-70-10, and 20-40-40 with 21038, 20709, and $20073 \mathrm{~kg} \mathrm{DM} \mathrm{ha}^{-1}$, respectively, and the lowest herbage yield was registered by monoculture with $12793 \mathrm{~kg} \mathrm{DM} \mathrm{ha}{ }^{-1}$. The associations with higher herbage yield exceeded that of monoculture by about $61 \%$. Independently of the association, in summer, the highest percentage was found to be orchard grass and in winter, it was white clover, while perennial ryegrass had the lowest percentage throughout the study. The associations of grasses and legumes have higher herbage yield when compared with the monoculture of orchard grass. The legume has a better behaviour when it is associated with perennial ryegrass and worse with orchard grass.
\end{abstract}

Key Words: association, grasses, legumes, performance

\section{Introduction}

The new requirements that worldwide agricultural production faces point not only to the competitive increase of agricultural production, but it also should be done in a sustainable manner. Sustainability should not be understood only in the ecological, but in the economic and social contexts (Arriaga et al., 1999). The grazing system of grasses associated with legumes undoubtedly constitutes one of the pillars of more sustainable and competitive ruminant production. Legumes are expected to become more important in the future (Lüscher et al., 2014).

Received: June 16, 2016

Accepted: June 27, 2017

*Corresponding author: rogarcia_05@hotmail.com

http://dx.doi.org/10.1590/S1806-92902017001200003

How to cite: Maldonado Peralta, M. A.; Rojas García, A. R.; Torres Salado, N.; Herrera Pérez, J.; Joaquín Cancino, S.; Ventura Ríos, J.; Hernández Garay, A. and Hernández Guzmán, F. J. 2017. Productivity of orchard grass (Dactylis glomerata L.) alone and associated with perennial ryegrass (Lolium perenne L.) and white clover (Trifolium repens L.). Revista Brasileira de Zootecnia 46(12):890-895.

Copyright (C) 2017 Sociedade Brasileira de Zootecnia. This is an Open Access article distributed under the terms of the Creative Commons Attribution License (http://creativecommons.org/licenses/by/4.0/), which permits unrestricted use, distribution, and reproduction in any medium, provided the original work is properly cited.
The associations of grasses and legumes allow for a higher nutritional value and dry matter yield, activity that allows to reduce the production costs in comparison with the use of balanced diets and, thus, ensure a higher production (Marquard et al., 2009; Mommer et al., 2010; Rojas et al., 2016a). From the ecological point of view, legumes improve soil fertility by fixing atmospheric nitrogen, reducing the use of chemical fertilizers, as well as provide better light interception and seasonal distribution of biomass production (Camacho and García, 2003; Gonzales et al., 2004). In this regard, Cook et al. (1990) and Rojas et al. (2005) mentioned that, in the temperate region of Mexico, white clover may contain an average of 168 to $270 \mathrm{~g}$ of crude protein $\mathrm{kg}^{-1} \mathrm{DM}$ and fix 57 to $232 \mathrm{~kg}$ of nitrogen ha ${ }^{-1}$ (Zanetti et al., 1999) and its association is preferred with grasses like perennial ryegrass and orchard grass.

Moreno et al. (2015) recorded an annual forage yield; the best association was 70:20:10 of perennial ryegrass, orchard grass, and white clover. During spring-summer, the perennial ryegrass monoculture and the 70:20:10 association of perennial ryegrass, orchard grass, and white clover obtained the highest forage yield. Villareal et al. (2014) and Hernández et al. (2015) reported, in monoculture of orchard grass, the highest yield in spring and summer 
and the lowest yield in fall and winter, regardless of the intensity and frequency of grazing. The association of white clover with orchard grass and perennial ryegrass yielded up to $52 \%$ more forage when the percentage of white clover in the sward was $40 \%$ and it could reach up to $65 \%$ more when grazing was done in spring-summer with a 28-day cut interval (Castro et al., 2012). Both parameters can be affected by the percentage of clover and grass in the sward, grazing every season (Karsten and Carlassare, 2002), as a consequence of the botanical components of the sward (Sanderson, 2010).

The objective of this research was to determine the productive capacity of orchard grass alone and associated with perennial ryegrass and white clover, sown in different proportions with the attributes seasonal and annual dry matter yield and botanical and morphological composition in two years of evaluation.

\section{Material and Methods}

The experiment was performed from September 2012 to September 2014 in Montecillo, Texcoco, the State of Mexico, located at $19^{\circ} 29^{\prime} \mathrm{N}$ and $98^{\circ} 53^{\prime} \mathrm{W}$, at an altitude of 2240 masl. The climate is temperate sub-humid, with annual rainfall of $636 \mathrm{~mm}$, mainly in summer (June to October), and mean annual temperature of $15{ }^{\circ} \mathrm{C}$ (García, 2004). The soil is a Typic Ustipsamments of loam-sandy texture, slightly alkaline with $\mathrm{pH} 7-8$, with $2.4 \%$ of organic matter (Ortiz, 1997).

The swards were established in February 2010, the sowing of grasses was done in rows $30 \mathrm{~cm}$ apart, while the legume was sown perpendicularly with a distance between rows of $30 \mathrm{~cm}$. The sowing density was different depending on the association based on monocultures; the densities of 20,30 , and $5 \mathrm{~kg} \mathrm{ha}^{-1}$, respectively, for orchard grass, perennial ryegrass, and white clover of viable pure seed, which was adjusted by the percentage of purity and germination of each species. The swards were not fertilized and in the dry season, they were irrigated to field capacity every two weeks. Before starting the research, a uniformity grazing with sheep was done, harvesting approximately $5 \mathrm{~cm}$ above ground level. Later, grazing was done every four weeks in spring-summer and every five and six weeks during fall and winter, respectively. It is important to mention that the sheep were used as defoliators and the experimental plots were managed with an electric fence.

The legume was sown in the associations in 10 and $50 \%$ minimum and maximum. The sowing treatments (February 2010) consisted of the following associations: 100-00-00, 70-20-10, 50-00-50, 40-40-20, 40-20-40,
$20-70-10,20-40-40$, and $00-50-50 \%$ of orchard grass, perennial ryegrass, and white clover, respectively. The eight treatments were randomly distributed into 24 experimental plots of $9 \times 8 \mathrm{~m}$.

To obtain the forage yield in each plot, two fixed frames of $0.25 \mathrm{~m}^{2}$ were randomly established at the start of the research where the present forage was harvested before grazing at a height of $5 \mathrm{~cm}$ above ground level. The forage present inside every frame was deposited in labelled paper bags. The samples were rinsed and exposed to a drying process in a forced-air oven at a temperature of $55{ }^{\circ} \mathrm{C}$ for $72 \mathrm{~h}$. The accumulated seasonal and annual yields were obtained by adding the yields per cut.

To obtain the botanical and morphological composition, a subsample of approximately $20 \%$ was taken from the forage samples harvested to determine yield one day before each grazing. Each subsample was separated into the different species sown (orchard grass, perennial ryegrass, and white clover) and unwanted species (other grasses and weeds) to determine the botanical composition. To determine the morphological composition of the desired species, they were separated into their morphological components (leaves, stems, and dead material). Every separate component was dried in a forced-air oven at $55{ }^{\circ} \mathrm{C}$ for $72 \mathrm{~h}$ and the dry weight of each component was determined. Later, the weights for each season in the two years of the research were averaged.

In the two years of the experiment, the mean monthly maximum temperature ranged between 20 and $27{ }^{\circ} \mathrm{C}$ in spring and summer (Figure 1). Meanwhile, the mean monthly
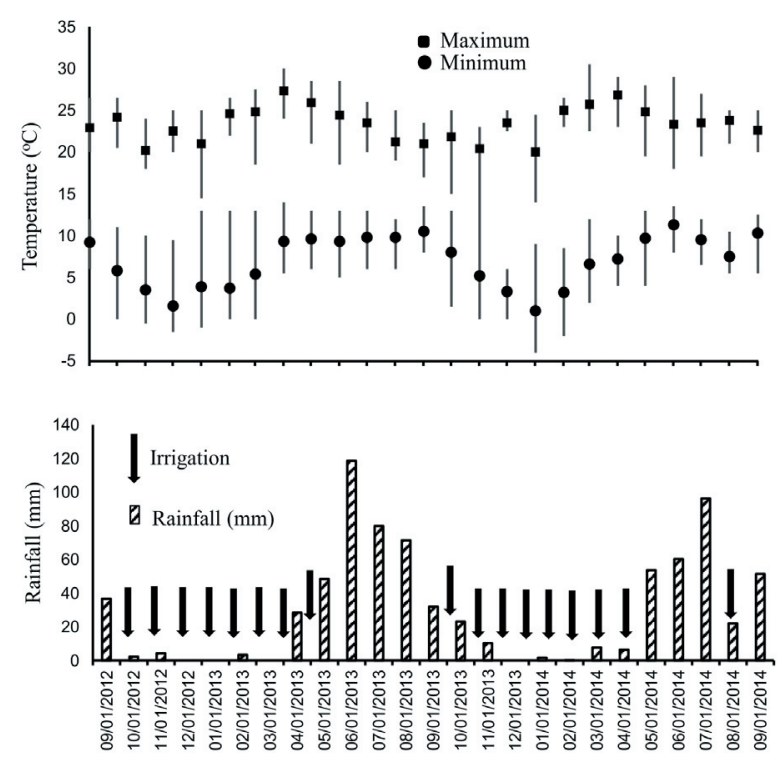

Figure 1 - Mean monthly maximum and minimum temperatures, accumulated precipitation, and irrigation to field capacity during the study period (09/2012 to 09/2014). 
minimum temperature ranged between 1 and $11.3{ }^{\circ} \mathrm{C}$, reaching, in the fall, the lowest temperature with an average of $3.6^{\circ} \mathrm{C}$. The accumulated precipitation in the first year was $409 \mathrm{~mm}$, with the highest precipitation, $270 \mathrm{~mm}$ $(66 \%)$, being in spring-summer of 2013 . The accumulated precipitation of the second year was $349 \mathrm{~mm}$, with the highest precipitation, $75 \%$ (261 $\mathrm{mm})$, in spring-summer of 2014. In the dry months, which cover mainly fall and winter of both years, the swards were irrigated to field capacity every two weeks.

An analysis of variance was done with the PROC GLM procedure of SAS (Statistical Analysis System, version 9.2.), in which the fixed effects were the associations, seasons, and years and their possible interactions. A Tukey mean test was used when significance was detected $(\mathrm{P}<0.05)$.

\section{Results}

In general, all the associations exceeded orchard grass alone $(\mathrm{P}>0.05)$. In both years, the associations $20-70-10$ and 40-20-40 of orchard grass, perennial ryegrass, and white clover recorded the highest annual yields, being statistically equal to the 20-40-40, 50-00-50, and 40-40-20 $(\mathrm{P}>0.05)$, in the first year, and to $20-40-40(\mathrm{P}>0.05)$, in the second year, respectively (Table 1). The mean annual yield of all associations during the first year (19006 $\mathrm{kg} \mathrm{DM} \mathrm{ha}^{-1}$ ) exceeded that of the second year $\left(17758 \mathrm{~kg} \mathrm{DM} \mathrm{ha}^{-1}\right)$ by $6.6 \%(\mathrm{P}<0.05)$ (Table 1$)$.

Regardless of the associations, statistical differences $(\mathrm{P}<0.05)$ were observed among seasons, in both years, with the following descending order: spring $>$ summer $>$ winter $>$ fall, with a mean of $6222,5472,3792$, and $2889 \mathrm{~kg} \mathrm{DM} \mathrm{ha}{ }^{-1}$, respectively. When comparing the yields per season between years, no statistical differences among them were registered $(\mathrm{P}>0.05)$.

Regarding the contribution of the desirable species to the annual yield, a decline of all species from the first to the second year of evaluation could be observed (Table 2). In both years, the species that contributed the most to the seasonal and annual yields was orchard grass (56.8\%), followed by white clover $(34.4 \%)$ and perennial ryegrass $(8.8 \%) \quad(\mathrm{P}<0.05)$. The associations that obtained the highest contribution of orchard grass in both years were 40-20-40, 20-40-40, 20-70-10, and 50-00-50 of orchard grass, perennial ryegrass, and white clover, outperforming orchard grass alone by $24.5 \%$ and $35 \%(\mathrm{P}<0.05)$ during the first and second years, respectively.

The associations that had the highest percentage of white clover in both years were 40-20-40 and 20-70-10 of orchard grass, perennial ryegrass, and white clover with an average of $6952 \mathrm{~kg} \mathrm{DM} \mathrm{ha}{ }^{-1}$, while the association 70-20-10 of orchard grass, perennial ryegrass, and white clover recorded the lowest yield with $4074 \mathrm{~kg} \mathrm{DM} \mathrm{ha}^{-1}(\mathrm{P}<0.05)$. When included as $10 \%$ of the mixture, white clover produces more if associated with perennial ryegrass compared with orchard grass. Similar results occurred when white clover was included as $50 \%$ of the mixture, producing more when associated to perennial ryegrass.

The species with lowest contribution to yield, from the start to the end of the research, was perennial ryegrass. The association with $50 \%$ of perennial ryegrass was the one that presented the highest yield of perennial ryegrass in both years with an average of $5269 \mathrm{~kg} \mathrm{DM} \mathrm{ha}^{-1}$.

There were changes in the mean botanical and morphological composition during the two years of research (Figure 2). In the fall, the species that had the highest

Table 1 - Annual and seasonal yields $\left(\mathrm{kg} \mathrm{DM} \mathrm{ha}^{-1}\right)$ of orchard grass (Dactylis glomerata $\left.\mathrm{L}.\right)$ alone and associated with perennial ryegrass (Lolium perenne L.) and white clover (Trifolium repens L.)

\begin{tabular}{|c|c|c|c|c|c|c|c|c|c|c|}
\hline \multirow{2}{*}{$\begin{array}{l}\text { Association } \\
\text { Or-Ry-Cl }\end{array}$} & \multicolumn{2}{|c|}{ Fall } & \multicolumn{2}{|c|}{ Winter } & \multicolumn{2}{|c|}{ Spring } & \multicolumn{2}{|c|}{ Summer } & \multicolumn{2}{|c|}{ Annual yield } \\
\hline & 2012 & 2013 & 2012 & 2013 & 2013 & 2014 & 2013 & 2014 & Year 1 & Year 2 \\
\hline $100-00-00$ & $1437 \mathrm{gE}$ & $1033 \mathrm{hE}$ & $2326 \mathrm{eE}$ & $1928 \mathrm{fE}$ & $5372 \mathrm{aE}$ & $4969 \mathrm{bE}$ & $4465 \mathrm{cF}$ & $4063 \mathrm{dF}$ & 13596D & 11993D \\
\hline $70-20-10$ & $2768 d \mathrm{dD}$ & $2465 \mathrm{dD}$ & $3551 \mathrm{cD}$ & $3243 \mathrm{cD}$ & $6058 \mathrm{aD}$ & $5748 \mathrm{aD}$ & $4994 b E$ & $4689 \mathrm{bE}$ & $17372 \mathrm{C}$ & $16183 \mathrm{C}$ \\
\hline $50-00-50$ & $3130 \mathrm{dC}$ & $2837 \mathrm{dC}$ & $3856 \mathrm{cC}$ & $3558 \mathrm{cC}$ & $6461 \mathrm{aC}$ & $6165 \mathrm{aC}$ & $5554 \mathrm{bD}$ & $5265 \mathrm{bD}$ & $19003 \mathrm{AB}$ & $17824 \mathrm{~B}$ \\
\hline $40-40-20$ & $3088 \mathrm{gC}$ & $2785 \mathrm{hC}$ & $4145 \mathrm{eBC}$ & $3840 \mathrm{fB}$ & $6687 \mathrm{aBC}$ & $6385 \mathrm{bBC}$ & $5891 \mathrm{cC}$ & $5589 \mathrm{dC}$ & $19823 \mathrm{AB}$ & 18601B \\
\hline $40-20-40$ & $3294 \mathrm{fBC}$ & $2997 \mathrm{gBC}$ & $4342 \mathrm{~dB}$ & $4048 \mathrm{eB}$ & $6848 \mathrm{bB}$ & $6549 \mathrm{cB}$ & $7153 \mathrm{aA}$ & $6856 \mathrm{bA}$ & 21639A & $20438 \mathrm{~A}$ \\
\hline $20-70-10$ & $3509 \mathrm{gB}$ & $3211 \mathrm{hB}$ & $4365 \mathrm{eAB}$ & 4067fAB & 7171aA & $6872 \mathrm{bA}$ & $6263 \mathrm{cB}$ & $5963 \mathrm{~dB}$ & 21309A & 20109A \\
\hline $20-40-40$ & $3926 \mathrm{gA}$ & $3696 \mathrm{hA}$ & $4611 \mathrm{eA}$ & $4317 \mathrm{fA}$ & $6531 \mathrm{aC}$ & $6235 \mathrm{bC}$ & $5603 \mathrm{cD}$ & $5309 d D$ & $20673 \mathrm{AB}$ & $19487 \mathrm{AB}$ \\
\hline $00-50-50$ & $3220 \mathrm{gC}$ & $2919 \mathrm{hC}$ & $4399 \mathrm{eAB}$ & 4098fAB & $5912 \mathrm{aD}$ & $5604 \mathrm{bD}$ & $5114 \mathrm{cE}$ & $4815 \mathrm{dE}$ & 18637B & $17433 B C$ \\
\hline Average & $3046 \mathrm{~cd}$ & $2733 d$ & $3949 c$ & $3636 \mathrm{c}$ & $6378 \mathrm{a}$ & $6066 a$ & $5629 b$ & $5316 b$ & $19006 \mathrm{a}$ & $17758 \mathrm{~b}$ \\
\hline SEM & 248 & 246 & 252 & 259 & 278 & 271 & 242 & 249 & 1048 & 1036 \\
\hline Significance & $* *$ & $* *$ & $* *$ & $* *$ & $* *$ & $* *$ & $* *$ & $* *$ & $* *$ & $* *$ \\
\hline
\end{tabular}

DM - dry matter; Or - orchard grass; Ry - perennial ryegrass; Cl - white clover; SEM - standard error of the mean.

$a b c-$ Means with the same lowercase letter in the same row are not different $(\mathrm{P}>0.05)$.

$\mathrm{ABC}$ - Means with the same uppercase letter in the same column are not different $(\mathrm{P}>0.05)$

$* * \mathrm{P}>0.05$. 
contribution were orchard grass and white clover with 38.5 and $37 \%$, respectively, and perennial ryegrass with $3.5 \%$, while the dead material, other grasses, and weeds contributed with $21 \%(\mathrm{P}<0.05)$. In the fall, the association $20-40-40$ of orchard grass, perennial ryegrass, and white clover presented the highest percentage of orchard grass with $50 \%$, while the associations $20-70-10$ and $70-20-10$ of orchard grass, perennial ryegrass, and white clover recorded the lowest values with $30 \%(\mathrm{P}<0.05)$. Also in the fall, the association that presented the highest percentage of white clover was 20-70-10 of orchard grass, perennial ryegrass, and white clover with $53 \%(\mathrm{P}<0.05)$.

The highest contribution of perennial ryegrass was obtained by the association with $50 \%$ perennial ryegrass with a mean of $26 \%(\mathrm{P}<0.05)$, while the highest contribution of weeds, other grasses, and dead material was presented by the orchard grass alone with $53 \%$. Regardless of the association, the species with the highest contribution in winter was white clover, with a mean of $50.5 \%$, followed by orchard grass, with $34 \%$, and perennial ryegrass with $4.5 \%$, while dead material, other grasses, and weeds together contributed 11\% $(\mathrm{P}<0.05)$. In this season, the association 40-20-40 of orchard grass, perennial ryegrass, and white clover recorded the highest percentage of white clover with $63 \%(\mathrm{P}<0.05)$.

In spring and summer, orchard grass predominated in all associations. During spring, on average, orchard grass contributed $59 \%$, white clover, $21.5 \%$, and perennial ryegrass $4.8 \%$; dead material, other grasses, and weeds contributed $14.7 \% \quad(\mathrm{P}<0.05)$. The highest contribution of orchard grass was found in summer, regardless of the associations or seasons, with $71 \%$. The contribution of other

Table 2 - Annual yield per species $\left(\mathrm{kg} \mathrm{DM} \mathrm{ha}^{-1}\right)$ of orchard grass (Dactylis glomerata L.) alone and associated with perennial ryegrass (Lolium perenne L.) and white clover (Trifolium repens L.)

\begin{tabular}{|c|c|c|c|c|c|c|c|c|}
\hline \multirow{2}{*}{$\begin{array}{l}\text { Association } \\
\text { Or- } \mathrm{Ry}-\mathrm{Cl}\end{array}$} & \multicolumn{3}{|c|}{ Year 1} & \multirow{2}{*}{ Total } & \multicolumn{3}{|c|}{ Year 2} & \multirow{2}{*}{ Total } \\
\hline & Orchard & Ryegrass & Clover & & Orchard & Ryegrass & Clover & \\
\hline $100-00-00$ & $8426 \mathrm{C}$ & - & - & $8426 \mathrm{E}$ & $6456 \mathrm{C}$ & - & - & $6456 \mathrm{E}$ \\
\hline $70-20-10$ & 9459B & $408 \mathrm{C}$ & $4375 \mathrm{C}$ & $14244 \mathrm{C}$ & $8408 \mathrm{~B}$ & $288 \mathrm{C}$ & $3774 \mathrm{C}$ & $12471 \mathrm{C}$ \\
\hline $50-00-50$ & $10561 \mathrm{AB}$ & - & $5248 B$ & $15810 \mathrm{C}$ & 9386AB & - & 4549BC & $13935 \mathrm{C}$ \\
\hline $40-40-20$ & $9105 \mathrm{~B}$ & $1283 B$ & $6654 \mathrm{AB}$ & $17042 \mathrm{BC}$ & $7843 \mathrm{BC}$ & 1074B & $5856 \mathrm{~B}$ & $14773 \mathrm{BC}$ \\
\hline $40-20-40$ & $11393 \mathrm{~A}$ & $231 \mathrm{C}$ & 7199A & 18824B & 10204A & $120 \mathrm{C}$ & $6373 \mathrm{AB}$ & 16699B \\
\hline $20-70-10$ & $11170 \mathrm{~A}$ & 1539B & $7532 \mathrm{~A}$ & $20242 \mathrm{~A}$ & $10040 \mathrm{~A}$ & 1394B & $6705 \mathrm{~A}$ & 18139A \\
\hline $20-40-40$ & $11557 \mathrm{~A}$ & $583 \mathrm{C}$ & $5663 \mathrm{~B}$ & $17804 \mathrm{BC}$ & $10030 \mathrm{~A}$ & $387 \mathrm{C}$ & 4949BC & $15367 \mathrm{BC}$ \\
\hline $00-50-50$ & - & $5840 \mathrm{~A}$ & $6784 \mathrm{AB}$ & $12625 \mathrm{D}$ & - & 4698A & 5439B & 10138D \\
\hline SEM & 897 & 745 & 789 & 1065 & 987 & 897 & 876 & 1088 \\
\hline Significance & $* *$ & $* *$ & $* *$ & $* *$ & $* *$ & $* *$ & $* *$ & $* *$ \\
\hline
\end{tabular}

DM - dry matter; Or - orchard grass; Ry - perennial ryegrass; Cl - white clover; SEM - standard error of the mean. $\mathrm{ABC}-$ Means with the same uppercase letter in the same column are not different $(\mathrm{P}>0.05)$. $* * \mathrm{P}>0.05$.
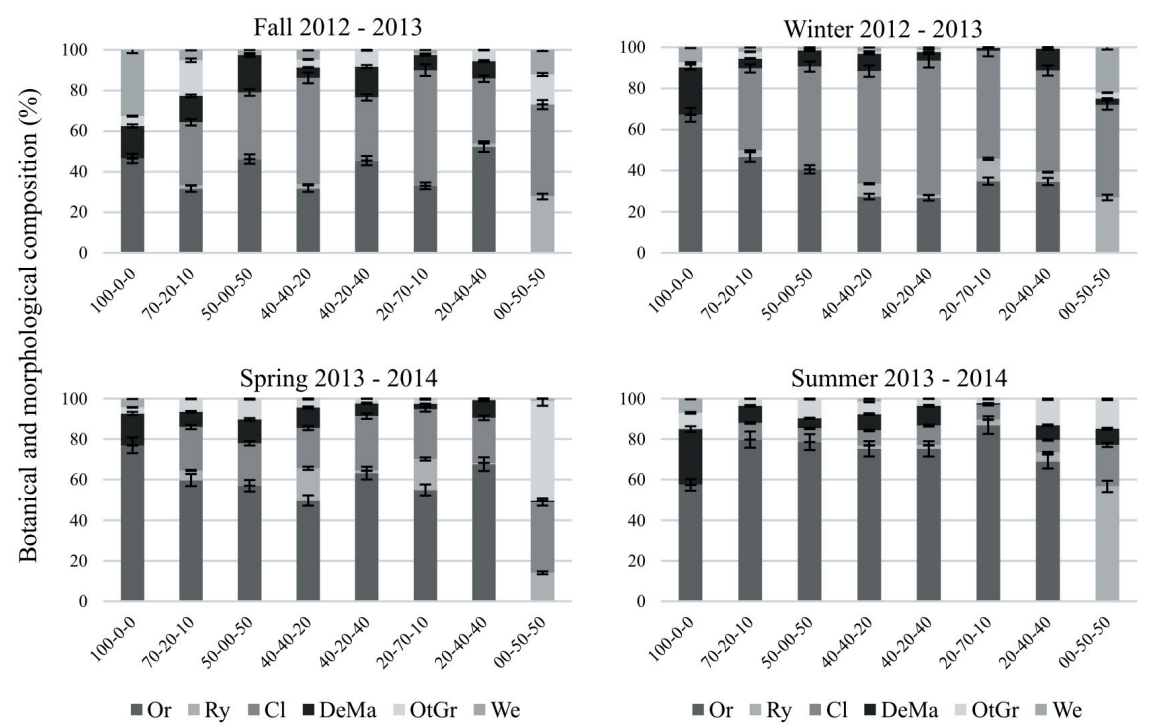

Or - orchard grass; Ry - ryegrass; Cl - clover; DeMa - dead material; OtGr - other grasses; We - weeds; I - standard deviation.

Figure 2 - Changes in the botanical and morphological composition of orchard grass (Dactylis glomerata L.) alone and associated with perennial ryegrass (Lolium perenne L.) and white clover (Trifolium repens L.). 
species was $8.5 \%$ perennial ryegrass, $8.5 \%$ white clover, and $12 \%$ dead material, other grasses, and weeds. In every season, the morphological component that prevailed was the leaf. All the associations presented a good contribution of desired species, with the exception of the association with $50 \%$ of perennial ryegrass and white clover, which, in spring, presented the highest amount of other grasses, with $51 \%$.

\section{Discussion}

In both years, the yield contribution was higher than those reported by Castro et al. (2012) and Moreno et al. (2015), when evaluating associations of grasses and legumes; however, they were similar to the results of Flores et al. (2015). Castro et al. (2012), when comparing five associations of orchard grass, perennial ryegrass, and white clover, reported in the best association (20:40:40), a mean annual production of $17275 \mathrm{~kg} \mathrm{DM} \mathrm{ha}^{-1}$. Meanwhile, Moreno et al. (2015), in seven associations with different proportions of the same species, observed values ranging from 7312 to $12611 \mathrm{~kg} \mathrm{DM} \mathrm{ha}^{-1}$ during the first year after being established.

A seasonal yield distribution similar to that observed in the present study was reported by Villareal et al. (2014) and Hernández et al. (2015), in swards of orchard grass alone, and by Castro et al. (2012), Flores et al. (2015), Moreno et al. (2015), and Rojas et al. (2016a,b), in associated swards of orchard grass, perennial ryegrass, and white clover in the Valley of Mexico. The highest seasonal yields were registered during spring and summer. This is attributed to the appropriate environmental conditions in both seasons, particularly temperature (Rojas et al., 2016a), which allowed the three species to express their full productive potential. However, the lower efficiencies in the fall can be attributed to the negative effect of low temperatures recorded during that period (Figure 1) (Horrocks and Vallentine, 1999), since to have the best growth, temperatures of 18 to $21{ }^{\circ} \mathrm{C}$ are required for perennial ryegrass and orchard grass, while for white clover, it is $24{ }^{\circ} \mathrm{C}$ (Brock and Tilbrook, 2000).

On the other hand, in studies done with seven grass and legume associations, Moreno et al. (2015) found that, independently of the association, perennial ryegrass contributed the most to the yield (47\%), followed by orchard grass $(21 \%)$ and white clover (13\%). The authors attributed this to the swards having been established for one year, since, during the first year, perennial ryegrass is the species that dominates because of its quick establishment, as orchard grass and white clover are slow to establish. However, in this research, a different behaviour was observed in the three species and it can be attributed to the established time of the prairie (2.5 years) and, therefore, the contribution to the mixture changes depending on the association, season, and growth habit (Rojas et al., 2016a).

The results of this research indicate that the potential of the associations of grasses with legumes, in comparison with orchard grass monoculture, is notable. The effects of complementarity and intra- and inter-specific interactions can make the use of the resources more efficient. This allows to save large amounts of nitrogen fertilizer and increase the yield of forage in intensive grazing systems (Nyfeler et al., 2009). In this regard, several researchers (Hooper and Dukes, 2004; Marquard et al., 2009; Mommer et al., 2010) have stated that associations of grasses with legumes exceed the forage yield of grasses alone. In a meta-analysis of 44 research works on associations and monocultures, Cardinale et al. (2007) found that the associations outperformed the yield of grasses alone by $70 \%$.

Moreover, in a research conducted by Nyfeler et al. (2011) in white clover and grass associations, they observed stimulatory effects of the grasses that accompanied the legume (symbiosis); the highest results were obtained in associations with white clover percentages between 40 and $60 \%$, in comparison with monoculture grasses. These percentages of white clover are similar to those found in the present research, $41 \%$ of white clover on average.

Regarding the botanical and morphological composition, similar results were reported by Moreno et al. (2015) and Rojas et al. (2016b), in which, in the fall and winter, the highest contribution of white clover to yield was found. This can be attributed to the stoloniferous growth habit of white clover (Durand et al., 1999), which allowed it to occupy the spaces left by the other species, particularly in the swards with high percentages of perennial ryegrass. Given that white clover grows well under shaded conditions, being associated with grasses might help it grow better, as it mitigates the low temperatures by occupying the lower strata and creating a microclimate that helped the best growth of the clover (Tallec et al., 2008; Nyfeler et al., 2011). The trend that orchard grass presents can be attributed to its resistance to higher temperatures, in comparison with perennial ryegrass (Durand el al., 1999).

\section{Conclusions}

The highest production of forage orchard grass is presented when it is associated with perennial ryegrass and white clover and the lowest when it is alone. There is seasonality, which indicates that in the stations with higher temperature, better structural characteristics are obtained in 
forage yield. The species with the lowest contribution is the perennial ryegrass.

\section{Acknowledgments}

We thank the Consejo Nacional de Ciencia y Tecnologia (CONACYT, Mexico) and the Colegio de Postgraduados (Mexico) for provision of post-graduate stipend and financial assistance.

\section{References}

Arriaga, J. C.; Espinoza, O. A.; Albarrán, P. and Castelán, O. O. 1999. Producción de leche en pastoreo de praderas cultivadas: una alternativa para el altiplano central. Ciencia Ergo Sum 6:290-300.

Brock, J. L. and Tilbrook, J. C. 2000. Effect of cultivar of white clover on plant morphology during the establishment of mixed pastures under sheep grazing. New Zealand Journal of Agricultural Research 43:335-343.

Camacho, G. J. L. and García, M. J. G. 2003. Producción y calidad del forraje de cuatro variedades de alfalfa asociadas con trébol blanco, ballico perenne, festuca alta y pasto ovillo. Veterinaria de México 34:151-177.

Cardinale, B. J.; Wright, J. P.; Cadotte, M. W.; Carroll, I. T.; Hector, A.; Srivastava, D. S.; Loreau, M. and Weis, J. J. 2007. Impacts of plant diversity on biomass production increase through time because of species complementary. Proccedings National Academy of Science of the USA 104:18123-18128.

Castro, R. R.; Hernández-Garay, A.; Vaquera, H. H.; Hernández, P. G. J.; Quero, C. A. R.; Enríquez, Q. J. F. and Martínez, H. P. A. 2012. Comportamiento productivo de asociaciones de gramíneas con leguminosas en pastoreo. Revista Fitotecnia Mexicana 35:87-95.

Cook, B. G.; Williams, R. J. and Wilson, G. P. M. 1990. Register of Australian herbage plant cultivars. B. Legumes. 21. Arachis. (a) Arachis pintoy Krap. et Grep. Nom. nud. (Pinto peanut) cv. Amarillo. Australian Journal of Experimental Agriculture 30:445-456.

Durand, J. L.; Schaufele, R. and Gastal, F. 1999. Grass leaf elongation rate as a function of developmental stage and temperature: Morphological analysis and modeling. Annals of Botany 83:577-588.

Flores, S. E. J.; Hernández-Garay, A.; Guerrero, R. J. D.; Quero, C. A. R. and Martínez, H. P. A. 2015. Productividad de asociaciones de pasto ovillo (Dactylis glomerata L.), ballico perenne (Lolium perenne $\mathrm{L}$.) y trébol blanco (Trifolium repens $\mathrm{L}$.). Revista Mexicana de Ciencias Pecuarias 6:337-347.

García, E. 2004. Modificaciones al sistema de clasificación climática de Koppen. 4ed. Universidad Nacional Autónoma de México. México, D. F. 217p.

González, A. S. X.; Días, S. H.; López, T. R.; Aizpuru, G. E.; Garza, C. H. M. and Sánchez, R. F. 2004. Consumo calidad nutritiva y composición botánica de una pradera de alfalfa y gramíneas perennes con diferentes niveles de asignación de forraje. Técnica Pecuaria en México 42:29-37.

Hernández, G. F. J.; Hernández-Garay, A.; Ortega, J. E.; Enríquez, Q. J. F. and Velázquez, M. M. 2015. Comportamiento productivo del pasto ovillo (Dactylis glomerata L.) en respuesta al pastoreo. Agronomía Mesoamericana 26:33-42.

Hooper, D. U. and Dukes, J. S. 2004. Overyielding among plant functional groups in a long-term experiment. Ecology Letters 7:95-105.

Horrocks, R. and Vallentine, J. F. 1999. Harvested forages. Academic Press, Oval Road, London, USA. 426p.
Karsten, H. D. and Carlassare, M. 2002. Describing the botanical compositions of a mixed species northeaster U. S. Pasture rotationally grazed by cattle. Crop Science 42:882-889.

Lüscher, A.; Mueller-Harvey, I.; Soussana, J. F.; Reess, R. M. and Peyraud, L. 2014. Potential of legume-besed grassland-livestock systems in Europe: a review. Grass and Forage Science 69:206-228.

Marquard, E.; Weigelt, A.; Temperton, V. M.; Roscher, C.; Schumacher, J.; Buchmann N.; Fischer, M.; Weisser, W. W. and Schmid, B. 2009. Plant species richness and functional composition drive overyielding in a six-year grassland experiment. Ecology 90:3290-3302.

Mommer, L.; Van Ruijven, J.; De Caluwe, H.; Smittiekstra, A. E.; Wagemaker, C. A. M.; Ouborg, N. J.; Bögemann, G. M.; Van Der Weerden, G. M.; Berendse, F. and De Kroon, H. 2010. Unveiling below-ground species abundance in a biodiversity experiment: a test of vertical niche differentiation among grassland species. Journal of Ecology 98:1117-1127.

Moreno, C. M. A.; Hernández-Garay, A.; Vaquera, H. H.; Trejo, L. C.; Escalante, E. J. A.; Zaragoza, R. J. L. and Joaquín, T. B. M. 2015. Productividad de siete asociaciones y dos praderas puras de gramíneas y leguminosas en condiciones de pastoreo. Revista Fitotecnia Mexicana 38:101-108.

Nyfeler, D.; Huguenin-Elie, O.; Seter, M.; Frossard, E.; Connolly, J. and Lüscher, A. 2009. Strong mixture effects among four species in fertilized agricultural grassland led to persistent and consistent transgressive overyielding. Journal of Applied Ecology 46:683-691.

Nyfeler, D.; Huguenin-Elie, O.; Suter, M.; Frossard, E. and Lüscher, A. 2011. Grass-legume mixtures can yield more nitrogen than legume pure stands due to mutual stimulation of nitrogen uptake from symbiotic and non-symbiotic sources. Agriculture Ecosystems and Environment 140:155-163.

Ortiz, S. C. 1997. Colección de Monolitos. Depto. Génesis de suelos. Edafología. IRENAT. Colegio de Postgraduados. Montecillo, Texcoco, Estado de México. 17p.

Rojas, H. S.; Olivares, P. J.; Jiménez, G. R. and Hernández, C. E. 2005. Manejo de praderas asociadas de gramíneas y leguminosas para pastoreo en el trópico. Revista Electrónica de Veterinaria 6:1-9.

Rojas, G. A. R.; Hernández-Garay, A.; Quero, C. A. R.; Guerrero, R. J. D.; Ayala, W.; Zaragoza, R. J. L. and Trejo, L. C. $2016 \mathrm{a}$. Persistencia de Dactylis glomerata L. solo y asociado con Lolium perenne L. y Trifolium repens L. Revista Mexicana de Ciencias Agrícolas 7:885-895.

Rojas, G. A. R.; Hernández-Garay, A.; Ayala, W.; Mendoza, O. S. I.; Joaquín, C. S.; Vaquera, H. H. and Santiago, O. M. A. 2016b. Comportamiento productivo de praderas con distintas combinaciones de ovillo (Dactylis glomerata L.), ballico perenne (Lolium perenne L.) y trébol blanco (Trifolium repens L.). Revista de la Facultad de Ciencias Agrarias UNCuyo 48:57-68.

Sanderson, M. 2010. Nutritive value and herbage accumulation rates of pastures sown to grass, legume and chicory mixtures. Agronomy Journal 102:728-733.

Tallec, T.; Diquélou, S.; Lemauviel, S.; Cliquet, J. B.; Lesuffleur, F. and Ourry, A. 2008. Nitrogen: sulphur ration alters competition between Trifolium repens and Lolium perenne under cutting: Production and competitive abilities. European Journal of Agronomy 29:94-101.

Villareal, G. J. A.; Hernández-Garay, A.; Martínez, H. P. A.; Guerrero, R. J. D. and Velasco, Z. M. E. 2014. Rendimiento y calidad de forraje del pasto ovillo (Dactylis glomerata L.) al variar frecuencia e intensidad de pastoreo. Revista Mexicana de Ciencias Pecuarias 5:231-245.

Zenetti, S.; Hartwig, A. U.; Lüscher, A.; Hebeisen, T.; Frehner, M.; Fischer, U. B.; Hendry, R. G.; Blum, H. and Nösberger, J. 1999. Simulation of symbiotic N2 fixation in Trifolium repens L. under elevated Atmospheric $\mathrm{pCO}_{2}$ in a grassland ecosystem. Plan Physiology 112:575-583. 